$\mathbb{P}$ periodica polytechnica

Civil Engineering

$56 / 1(2012) 25,34$

doi: 10.3311/pp.ci.2012-1.03

web: http://www.pp.bme.hu/ci

(c) Periodica Polytechnica 2012

RESEARCH ARTICLE

\section{Different FEM models of reinforced concrete frames stiffened by infill masonry for lateral loads}

\author{
István Haris / Zsolt Hortobágyi
}

Received 2011-10-19, revised 2011-11-11, accepted 2012-12-12

\begin{abstract}
The aim of the paper is to introduce how to model more accurate masonry infilled reinforced concrete frames with commercially available FEM software. We developed some numerical models. One question is how to model the infill masonry for monotonic increasing lateral load? Three different numerical models were investigated. The simplest model is the equivalent diagonal strut model, where the masonry wall is replaced by a compressed diagonal strut. The next model is the orthotropic surface model, where the masonry wall is taken into account as a membrane or shell surface. Between the RC frame and the boundary of the surface are modelled with special spring and contact elements. The last model is called "suggested sophisticated model", where the bricks and the mortar layers are separately modelled. The brick is taken into consideration as an orthotropic membrane element, while the mortar layers are substituted with short perpendicular and diagonal equivalent compressed struts. In case of all models small displacements are assumed. We give the necessary data to the material properties in accordance with Eurocode 6. In this paper "only" one numerical example is presented to demonstrate the operability of the different models. In the next step the practical usability and the verification with experiment results of the different models will be presented in another article.
\end{abstract}

\section{Keywords}

masonry infilled RC frames $\cdot$ numerical modelling of infill masonry wall $\cdot$ material characteristics of the masonry infill

\section{István Haris}

Budapest University of Technology and Economics, Department of Structural Engineering, H-1111, Budapest, 3-9. Múegyetem rkp., fszt. 85., Hungary e-mail: haris@vbt.bme.hu

\section{Zsolt Hortobágyi}

Budapest University of Technology and Economics, Department of Structural Mechanics, H-1111, Budapest, 3-9. Múegyetem rkp., fszt. 63., Hungary e-mail: zsolt@hortobagyi.com

\section{Introduction}

In Hungarian engineering practice, the global horizontal stiffness of buildings with reinforced concrete frames is ensured mostly by so-called connected or individual stiffening wall systems. Filling reinforced concrete frames with infill masonry serving as partitions are very common. In structural design, such infill masonry walls are considered as non-load bearing, non primary structural elements. Only the concrete skeleton is assumed to carry horizontal and vertical loads. Stiffening walls are mostly realized in the form of cast-in-situ reinforced concrete walls in Hungary. However, the infill masonry walls resist loads and reduce deformations too. Understanding the behaviour the masonry infilled concrete frames will help the structural engineers to have more realistic and useful structural solutions.

This article presents three different finite element modelling methods - taking practical aspects into consideration - of the infill masonry walls for lateral loads according to Eurocodes.

\section{Historical review}

Many analytical and experimental studies have been published during the last 50-60 years. All of the articles show that infilled concrete frames have greater stiffness and strength compared to unfilled frames. Otherwise due to changes in stiffness and mass, dynamic characteristic/response of the whole structure, buildings also change (Magenes, Pampanin 2004; Bell, Davidson 2001; Puyol et al. 2008; Dincel 2009). The infill masonry has an effect on both global and local failure modes, new and unexpected (compared by the unfilled frames) and neglected failure modes could be appeared (Shing, Mehrabi 2002).

After Polyakov's investigations (1957) Holmes (1961) replaced the infill masonry by an equivalent compressed diagonal strut, which is between the loaded corners of the concrete skeleton, made of the same material, and having the width $1 / 3$ of the diagonal length. Smith $(1962,1966)$ and Smith at al. (1969) related the width of the equivalent strut to in the ratio of the stiffness of the infill and the bare frame. This method will be examined in this article according to Eurocode 6 (MSz-EN 1996-1-1:2009). Mainstone $(1971,1974)$ replaced the theoretical equations with empirical relations. 
Because of the elastic theories could not exactly represent the real behaviour of the infilled concrete frames, from the 70's in order to specify the methods the attention principally was paid to theories of plasticity (Wood 1978; May 1981; Dawe et al. 1989). Finally Saneinejad and Hobbs (1995) published a re'sume' article included the main results, which are taken the pillar of this theme by nowadays researchers.

Using the standard models, which were determined by Shing and Mehrabi (2002), the strength of the infilled concrete frame could be calculated relative easily and quickly. The most common five different failure modes (Fig. 1) of the one-storey, onebay infilled concrete frames, and each of the belonging ultimate load carrying capacities were defined. The lowest one is the effective ultimate load carrying capacity.

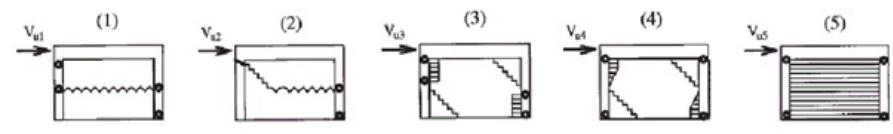

Fig. 1. Failure modes of the one-bay, one-storey infilled concrete frames (Shing and Mehrabi 2002)

By analytical and numerical results in most cases Failure 2 and 5 (Fig. 1) are dominating in case of using "weak" and in “strong" infill masonry (Fig.2).

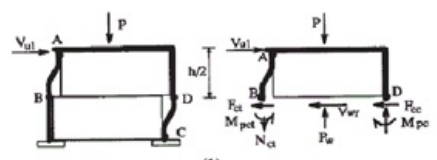

(1)

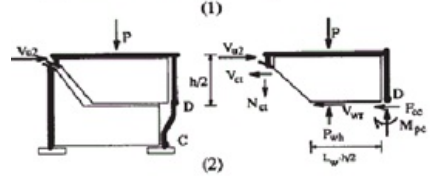

(2)
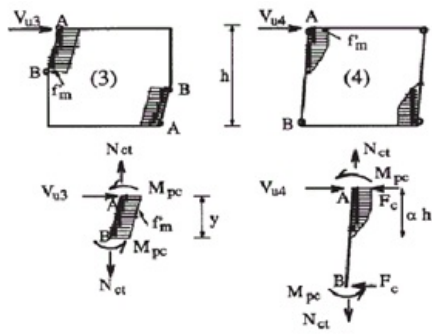

Fig. 2. Elementary frame forces (Shing és Mehrabi 2002)

Special attention has been nowadays given to the examination of the lateral cyclic horizontal loading, especially the seismic vulnerability of the masonry infilled concrete frames. By the evolution of the softwares using in structural design process many analytical and numerical models and results (Lourenço et al. 2006, Puglisi et al. 2009) were published in the international scientific literature. Above all many experimental results also were presented in connection with the masonry infilled steel frames (Seah 1998; Tasnimi, Mohebkhah 2011) and concrete frames (Murty, Jain 2000; Braz-Cesar et al. 2008, Baran, Sevil 2010).

\section{Equivalent compressed strut model}

Stiffening walls are characteristically dimensioned for horizontal actions (e.g.: wind loads, earthquake effect). When producing an equivalent compressed strut model, cast-in-situ reinforced concrete structures (pillars, beams) are taken into consideration with their actual geometric and material characteristics in the calculation, whereas infill masonries are modelled by a so-called equivalent diagonal compressed strut (Fig. 3.

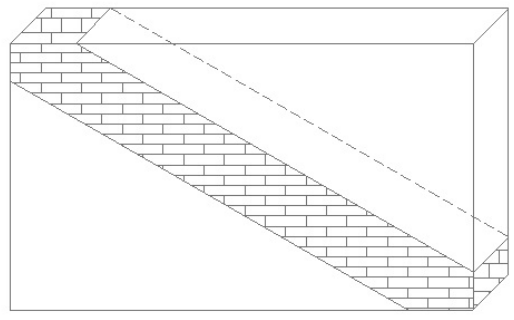

Fig. 3. Interpretation of an equivalent diagonal compressed strut

The horizontal actions are reduced to the nodes specified along the respective floor slab levels; then the stresses are determined in the compressed diagonal strut, which is supported by hinges at both ends. The static scheme of the model is shown in Fig. 4, and of course small displacements are assumed:

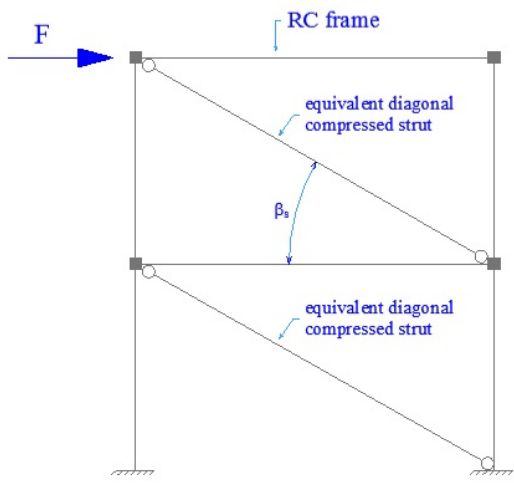

Fig. 4. Static scheme of equivalent compressed strut model

The cross-sectional parameters of this equivalent strut could be calculated with the following formulas (Smith 1962, 1966, Smith and Carter 1969):

$$
\begin{aligned}
& a_{\text {infill }}=0.175\left(\lambda h_{\text {col }}\right)^{-0.4} d \\
& \lambda=\sqrt[4]{\frac{E_{\text {infill }} b_{w} \sin \left(2 \beta_{s}\right)}{4 E I h_{\text {inf }}}}
\end{aligned}
$$

where $a_{\text {infill }}$ is the effective width of the equivalent diagonal strut, $\lambda$ is a dimensionless parameter, $h_{c o l}$ is the height of the concrete column between the centrelines of the beams in one storey, $d$ is the diagonal length of the infill masonry, $E_{\text {infill }}$ is the Young's modulus of the infill, $b_{w}$ is thickness of the masonry, $\beta_{s}$ is the angle of the diagonal see on Fig. 4, $E$ is the Young's modulus of the concrete column, $I$ is the moment of inertia of the concrete column, $h_{\text {inf }}$ is the height of the infill masonry.

The material characteristics must always be specified in accordance with the rules of the applicable standard. Nowadays in Hungary this standard is the EN 1996 Eurocode 6: Design of masonry structures (Dulácska 2009). The specifications for unreinforced masonries are the followings:

- determination of the characteristic compressive strength (using general purpose mortar):

$$
f_{k}=K f_{b}^{0.7} f_{m}^{0.3}
$$


where the value of $K$ depends on the density of the used mortar and the type of the masonry units, $f_{b}$ is the normalized compressive strength of the masonry units in $\mathrm{N} / \mathrm{mm}^{2}, f_{m}$ is the specified compressive strength of the general purpose mortar in $\mathrm{N} / \mathrm{mm}^{2}$.

- the secant Young's modulus of the masonry for use in the structural analysis for compression in perpendicular to bed joint:

$$
E_{\text {sec }}=1000 f_{k}
$$

- for the calculations relating to the serviceability limit state a secant modulus is suggested:

$$
E_{\text {infill }}=0.6 E_{\text {sec }}
$$

- the shear modulus:

$$
G_{\text {infill }}=0.40 E_{\text {infill }}
$$

These formulas are quite compacts, we just need to specify the material data of the masonry infill. Since the infill masonry is diagonally compressed when the infilled frame is loaded laterally, El-Dakhakhni et al. (2003) made an assumption that the compression properties in the diagonal direction are the necessary material properties. Because of the masonry infill wall is anisotropic, another assumption was made by considering the anisotropic infill as orthotropic. The Young's modulus in diagonal $\left(\beta_{s}=\beta\right)$ (see on Fig. 4) direction shall be calculated with Formula (7):

$$
\begin{aligned}
\frac{1}{E_{\text {infill. } \beta}}= & \frac{1}{E_{\text {infill. } 0}} \cos ^{4} \beta+\frac{1}{E_{\text {infill. } 90}} \sin ^{4} \beta \\
& +\left[-\frac{2 v_{0-90}}{E_{\text {infill. } 0}}+\frac{1}{G_{\text {infill }}}\right] \cos ^{2} \beta \sin ^{2} \beta
\end{aligned}
$$

where $E_{\text {infill. }}$ and $E_{\text {infill.90 }}$ are Young's modulus of the infill masonry in the direction to parallel and perpendicular to the mortar bed joints, $v_{0-90}$ is Poisson's ratio, $G_{\text {infill }}$ is shear modulus. $E_{\text {infill.0 }}$ could be taken as half of $E_{\text {infill.90, and }}$ $v_{0-90}=0.25$.

The assumption that compressive strength of the infill masonry is different to according to the angle of the diagonal forces was investigated by Hamid and Drysdale (1980) and finally the value of the ultimate strength of the infill masonry in the direction $\beta, f_{\text {infill }-\beta}$ was suggested to calculate with Formula (8):

$$
f_{\text {infill- } \beta}=0.7 f_{\text {infill-90 }}
$$

Substitute $f_{\text {infill-90 }}$ by $f_{k}(3)$ :

$$
f_{\text {infill- } \beta}=0.7 f_{k}
$$

In case of non-linear finite element analysis Saneinejad and Hobbs (1995) suggested that the secant stiffness of the infilled frames at the peak load let be half of the initial stiffness. This suggestion can be adapted to the calculation of the Young's modulus in Formula (10):

$$
E_{\text {infill-peak }}=0.5 E_{\text {infill. } \beta}
$$

It is advantageous that above mentioned calculation could be performed easily.

Perhaps the major disadvantage of this model is that although the equivalent compressed diagonal strut can be defined by nonlinear material characteristics, still only axial forces can be generated in the strut, therefore the tension perpendicular to the pressure (Poisson's effect) cannot be examined in the brick wall. Furthermore, the connection between the reinforced concrete frame and the brick wall cannot be modelled at all; only an ideal joint can be taken into account, which may significantly differ from the real behaviour.

\section{Mesh surface model}

The reinforced concrete frame can be modelled by several types of linear (one dimensional) elements; however, it is expedient to apply elements capable to take shear deformations into consideration as well.The infill masonry wall is modelled either by plane stress membrane elements in the state of planar deformation, or by plane shell elements in accordance with its actual location with the assumption of small deformations.

In order to model the connection between the reinforced concrete frame and the brick wall we defined springs demonstrating nonlinear behaviour along the edges of connection as well as contact elements (Haris, Hortobágyi 2007). By reason of the easier specification of stiffness characteristics, it is advisable to define a regular FEM mesh distribution which is even along the contact elements (Fig. 5). For the more sophisticated results at corner regions, where the local failure modes will be evolved in the masonry, the contact connections can be concentrated by the mesh refine (Fig. 5).

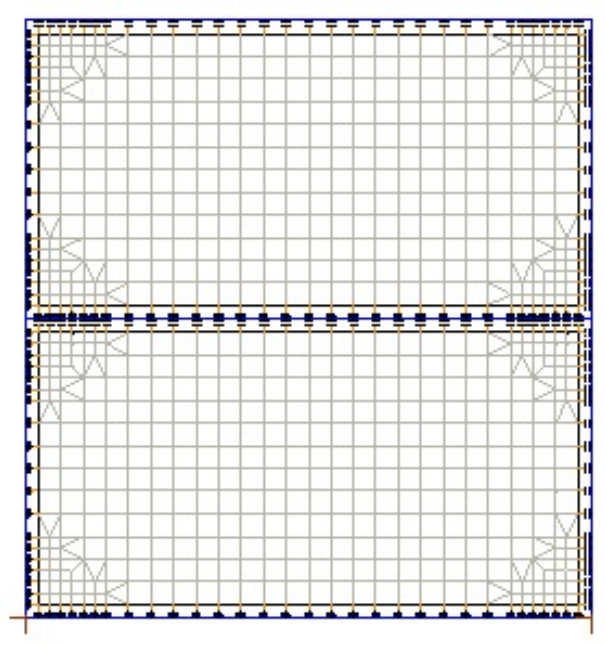

Fig. 5. Mesh design

In order to be able to model the connection between the steel reinforced concrete frame and the masonry wall, a spring and a 
contact element are aligned 'serially' as in Fig. 6 A fictitious weak spring support of the lateral displacement of the node between the 'serially connected' elements is required so that the stiffness matrix of the structure should not become singular.

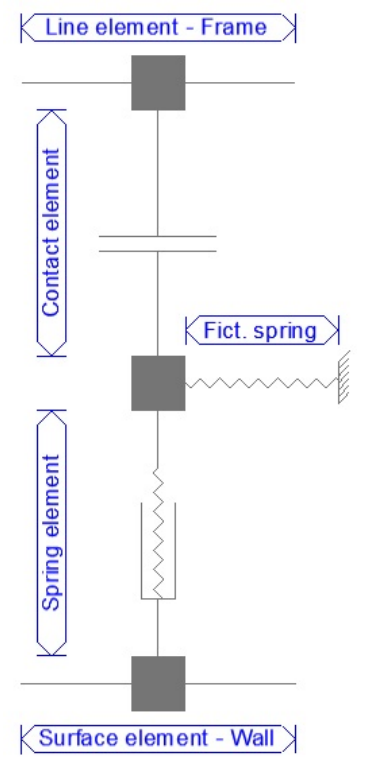

Fig. 6. Static scheme of connection model

The contact element is designed to make a connection between the reinforced concrete structural element and the brick wall. These elements work together only to the impact of pressure. In the present case, it is a property of the FEM software applied that the nonlinearity of the behaviour of the contact element means that it cannot take up tension, but to the impact of compression it demonstrates perfect linear elasticity(Fig. 7).

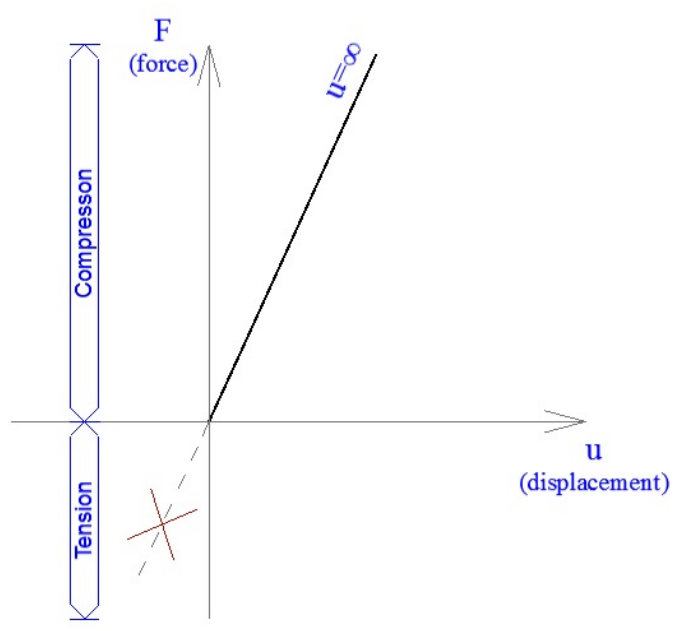

Fig. 7. Behaviour of contact element

The spring element ensures the control of the upper limit value of resistance generated along the contact area in a form that the element can be uniquely associated with the design value of load bearing $\left(F_{R d}\right)$ (Fig. 8 ).

Usually the behaviour of the spring is specified with a spring constant $(\rho)$, what can be calculated with Formula (11):

$$
\rho_{\text {spring }}=E_{m} \frac{t_{\text {infill }} \ell_{\text {spring }}}{v_{\text {mortar }}}
$$

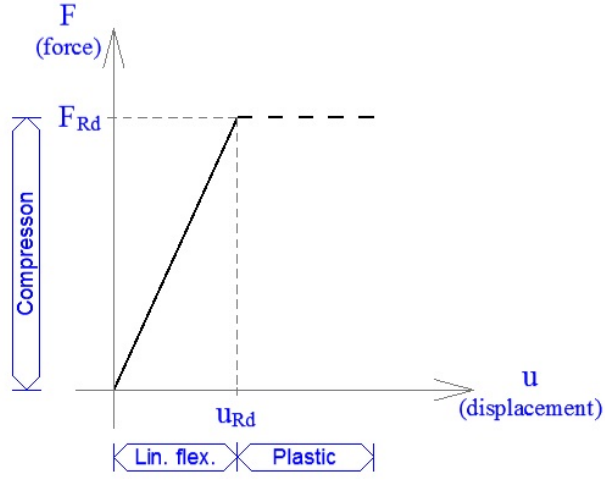

Fig. 8. Joint behaviour of the contact and spring elements

where $E_{m}$ is the Young's modulus of bed mortar, approximately (it is estimation in accordance with EC) could be substituted with $E_{\text {infill; }}$ see in (5), $t_{\text {infill }}$ is the thickness of the infill masonry could be replaced with $0.8 b_{w}$; see in (2), $\ell_{\text {spring }}$ is the distance between spring elements in the FEM model, $v_{\text {mortar }}$ is the thickness of the mortar between the brick elements and concrete skeleton.

Thereby the spring element can be used for modelling the failure of node connections, meaning that after reaching the load bearing capacity of a connection element $\left(F_{R d}\right)$, the next contact elements will be loaded effect to the increasing external lateral load.

The fictitious weak spring supports the node between the above mentioned spring and contact elements. It is required so that the stiffness matrix of the structure should not become singular, so its spring constant could be a numerically small value, but larger, than 0 .

The characteristic values of the used materials of the given infill masonry shall be calculated according to the applicable standard with orthotropic behaviour, in this case according to the Eurocode 6, see in Chapter 3, Formula (5) and (6), see Fig. 9 .

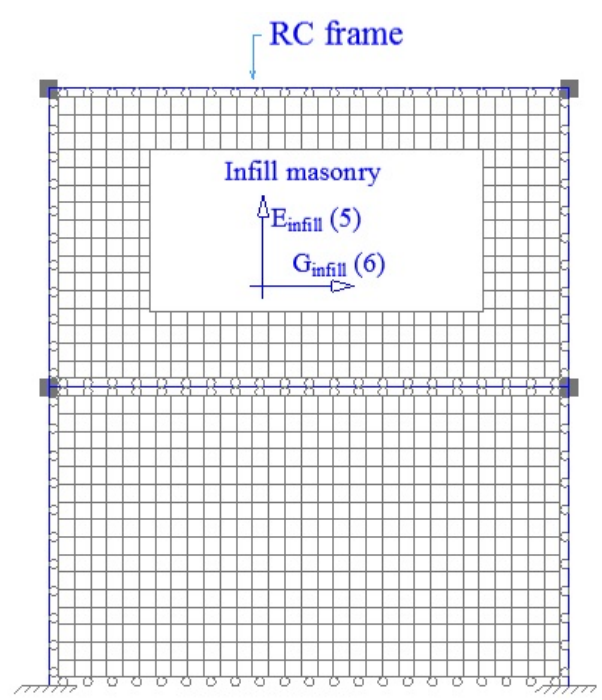

Fig. 9. Orthotropic shell elements according to EC6

Of course, as it was mentioned in the previous chapter, the material characteristics of the infill masonry could not be 
enough correct to represent the real deformations of the infilled frame, so the suggestions need to be taken into consideration as well as it was presented in the previous chapter.

In case of doubt the numerical values of the material characteristics can be determine with the help of experimental results (Fódi, 2011).

\section{Suggested sophisticated model}

The infill masonry panel can be modelled by modelling each brick elements and mortar layers. In the calculations small displacements are assumed. Brick elements used in nowadays construction practise in Hungary in good approximation could be taken into consideration with orthotropic model. The real orthotropic characteristic values of the brick element can be relative easily measured (Fódi, 2011), at any rate definitely easier than measuring the whole masonry. The common used mortar in Hungary shall be modelled approximately as a weak concrete.

In order to assemble a more sophisticated FEM model, the brick elements and the mortar layers shall be modelled separately, this method is called "Suggested sophisticated model" in this paper. At the followings we give a method how an infill masonry could be modelled in details.

First of all we have to mention that the connectors, which were introduced in the previous chapter, will be used in this model too.

A brick element could be taken into consideration as an orthotropic shell element or more than one shell elements, so it is sufficient to take the Young's modulus and the strengths in two perpendicular directions and the Poisson's ratio (Fig. 10). These main data could be usually found in the Manufacturer's Manual, but often only one of the these two different directions is given, the perpendicular one must be calculated approximately as the half of the other one.

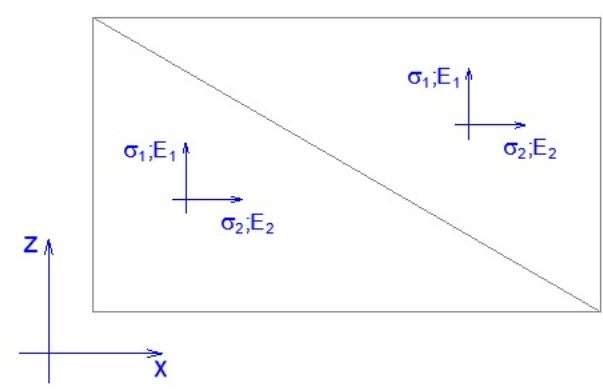

Fig. 10. Orthotropic shell model of each brick elements

Before modelling, take a review of the behaviour of the mortar layers. In good approach the mortar could only transmit compression and shear forces inside the infill masonry, because the transmitted tension forces could be as big as the adhesion is between the masonry unit and mortar or the tensile strength related to contact surface between mortar and brick.

The joint behaviour of the masonry unit and the mortar layer is considerably nonlinear, the mortar layer could not be modelled with another shell finite elements with the common FEM softwares used in the designer's practice. To model the nonlinear connection between the brick element and the mortar layer, such as shell finite elements should be used are only work for compression, which is very difficult and make the whole model so complicated and non-usable in everyday practice. So the mortar layers shall be modelled with equivalent compressed struts. But only normal stiffness could be integrated into a strut element, namely a Young's modulus $(E)$ and a cross-sectional area $(A)$. Contrarily the mortar layer has shear strength too, so near the strut, which is perpendicular to the longitudinal direction of the bed mortar layer, another finite element, a slanting strut must be used too (Fig. 11).

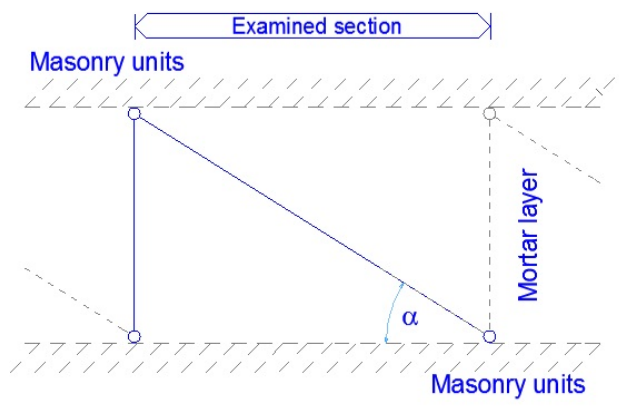

Fig. 11. Equivalent normal and slanting struts modelling the mortar layer

We can see on Fig. 11, that well distinct sections could be defined in the mortar layer. But in one elementary cell, which can be marked off freely between the brick elements, the same material characteristic values, $(E A)$ normal stiffness could not be used at both struts, because both compression and shear strengths have to be ensured. For clear this problem, examine the behaviour of an elementary cell. The target is to define the normal stiffness $(E A)$ of both the perpendicular and the slanting strut.

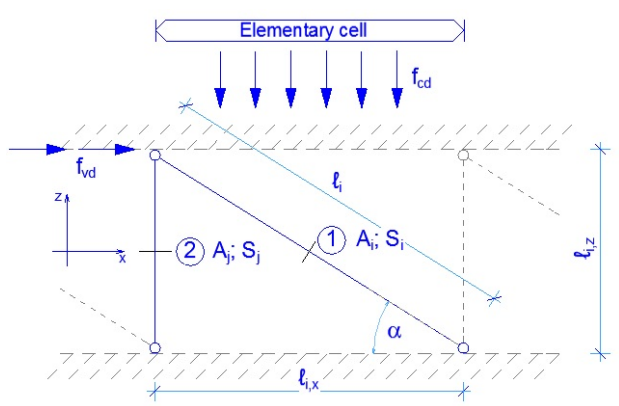

Fig. 12. Equivalent normal and slanting struts, modelling the mortar layer

First of all define the equilibrium state of an elementary cell:

$$
\begin{array}{ll}
\sum F_{i, x}: & A_{i} f_{m d} \cos \alpha=f_{\nu d} \ell_{i, x} v_{i n f} \\
\sum F_{i, z}: & A_{i} f_{m d} \sin \alpha+A_{j} f_{c d}=f_{c d} \ell_{i, x} v_{i n f}
\end{array}
$$

where $A_{i}$ and $A_{j}$ are the cross-sectional area of the equivalent struts, $f_{m d}$ is the design value of the compression strength of the mortar, $f_{v d}$ is the design value of the shear strength of the mortar, $v_{\text {inf }}$ is the thickness of the wall, see $\ell_{i}$ and $\ell_{i, x} ; \ell_{i, z}$ on Fig. 12 $S_{i}$ and $S_{j}$ are the normal forces in the strut. 
Find $A_{i}$ from Equation 12 and $A_{j}$ from Equation 13 :

$$
\begin{aligned}
& A_{i}=\frac{f_{\nu d} \ell_{i} v_{i n f}}{f_{m d}} \\
& A_{j}=\ell_{i, x} v_{i n f}-A_{i} \frac{\ell_{i, z}}{\ell_{i}}
\end{aligned}
$$

Substitute Equation (14) into Equation (15):

$$
A_{j}=\ell_{i, x} v_{i n f}-\frac{f_{v d} v_{i n f} \ell_{i, z}}{f_{m d}}
$$

Using Equation (14) and (16) both of the equivalent struts' cross-sectional areas can be calculated.

The deformations of the original compressed and sheared elementary cell must be equal to the deformations of the equivalent strut model, see Fig. 13
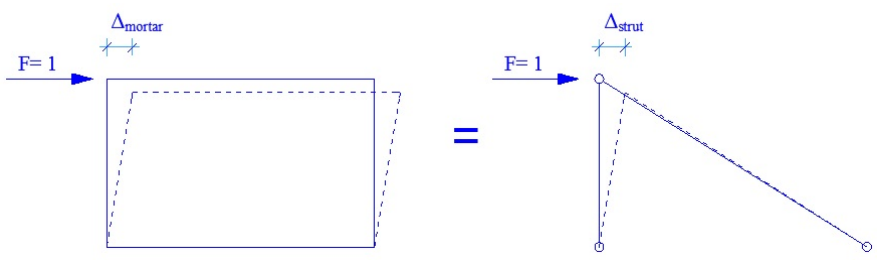

Fig. 13. Compatibility condition

The compatibility condition is the following:

$$
\Delta_{\text {mortar }}=\Delta_{\text {struct }}
$$

In the main directions:

$$
\Delta_{m, x}=\Delta_{s, x} \quad \text { and } \quad \Delta_{m, z}=\Delta_{s, z}
$$

To calculate each of the equivalent Young's modulus of the struts Unit Force Method is used:

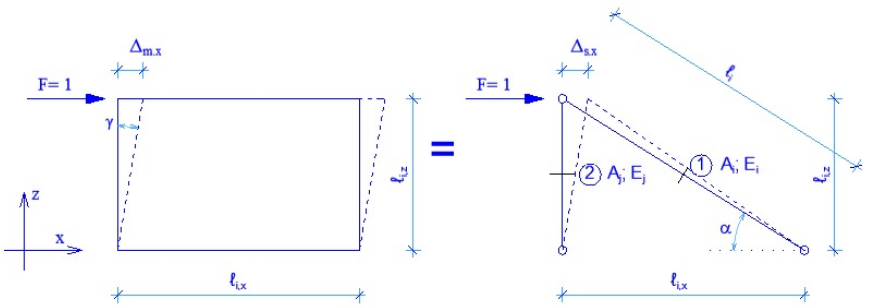

Fig. 14. Compatibility condition in direction " $\mathrm{x}$ "

First in local direction " $\mathrm{x}$ " (Fig. 14):

$$
\gamma \ell_{i, z}=\tan ^{2}(\alpha) \ell_{i, z} \frac{1}{E_{j} A_{j}}+\frac{1}{\cos ^{2} \alpha} \ell_{i} \frac{1}{E_{i} A_{i}}
$$

$\gamma$ is the following, when the horizontal force $F$ equals 1 :

$$
\gamma=\frac{1}{G_{m} \nu_{i n f} \ell_{i, x}}
$$

where $G_{m}$ is the shear modulus of the mortar.

Than in local direction " $z$ " (Fig. 15):

$$
\frac{1}{v_{i n f}} \frac{\ell_{i, z}}{\ell_{i, x}} \frac{1}{E_{m}}=\ell_{i, z} \frac{1}{E_{j} A_{j}}
$$
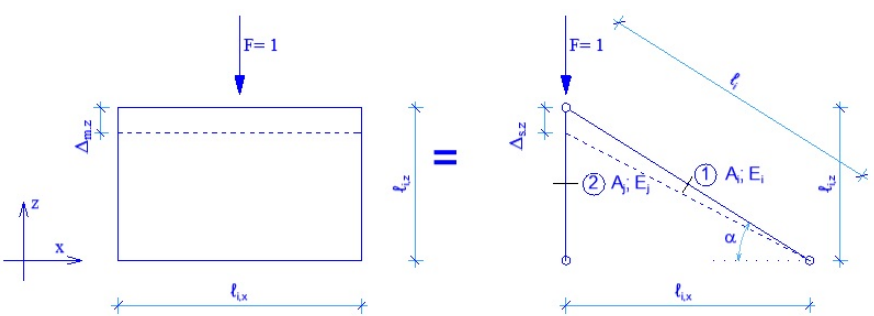

Fig. 15. Compatibility condition in direction " $\mathrm{z}$ "

where $E_{m}$ is the Young's modulus of the mortar.

Using the connection between the shear and Young's modulus of the mortar:

$$
G_{m}=\frac{E_{m}}{2\left(1+v_{m}\right)}
$$

The equivalent Young's modulus of each strut can be calculated by Formula 23, and 24.

$$
\begin{aligned}
E_{j} & =\frac{E_{m} \ell_{i, x} v_{i n f}}{A_{j}} \\
\frac{1}{E_{i}} & =\frac{A_{i}}{E_{m} v_{i n f}}\left[\frac{\ell_{i, z} \ell_{i, x}}{\ell_{i}^{3}} 2\left(1+v_{m}\right)-\frac{\ell_{i, z}^{3}}{\ell_{i}^{3} \ell_{i, x}}\right] .
\end{aligned}
$$

In Formula (14); (16); 23) and 24) all of the parameters are computable if the geometrical and the material data of the infill masonry are known. So the equivalent normal stiffness $\left(E_{i} A_{i}\right.$ and $E_{j} A_{j}$ ) of the struts can be calculated by Eurocode 6, either the masonry unit's material characteristics are.

\section{Brief introduction to the FEM software applied}

The procedures presented can be used by practicing engineers to examine the joint behaviour and load bearing capacity of the two different structural components by any FEM software.

Therefore our aim is to complete the calculation using commercially available software in a way to approximate reality better.

In the present case, modelling was performed using the FEM software AxisVM 11.

The software applies isoparametric plain quadrilateral (8/9node) or triangular (6-node) elements to model surfaces. Their shape functions are of the second degree. 3-node rib elements are recommended for modelling linear elements as they also take the shear deformations into account in the calculations.

It is important to note, however, that any other commercially available FEM software can be used to complete the procedures presented; the software is only required to have these types of finite elements.

\section{Results}

The modelling procedures are presented on a structure (see Fig. 16 on the basis of a current experimental research, which is under construction at BME Laboratory in Hungary, using the software mentioned in the previous section. 


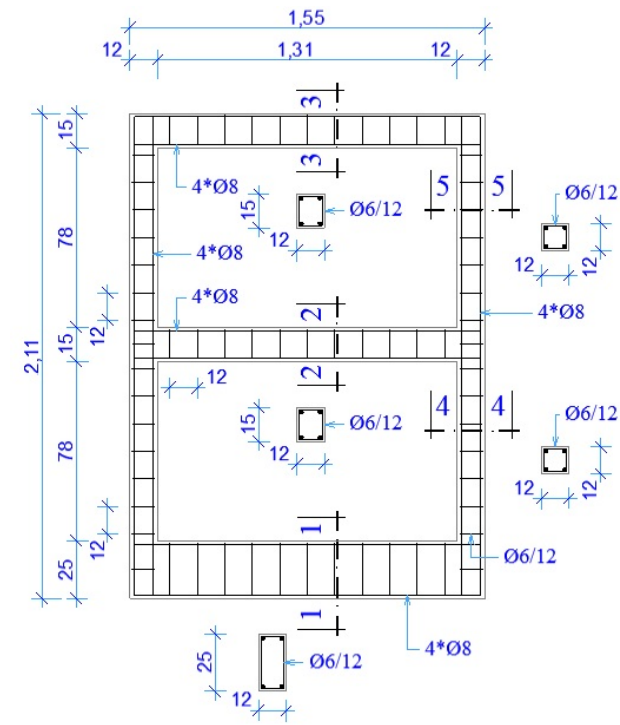

(a) Construction plan of the RC frame

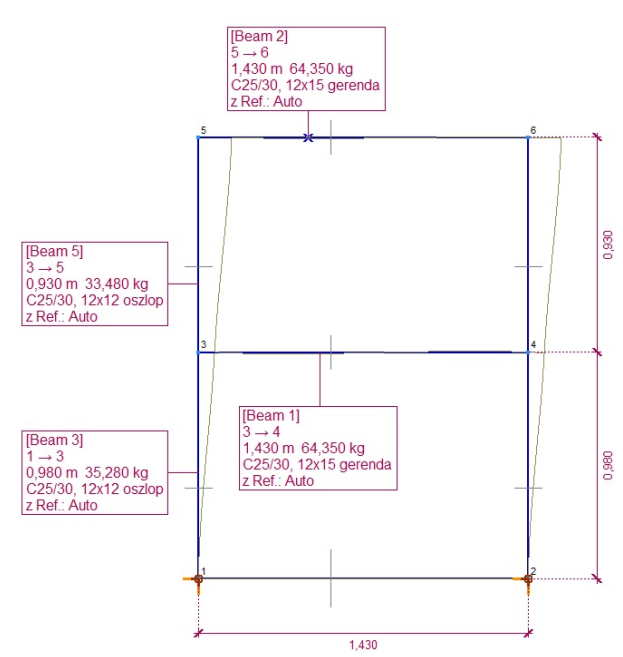

(b) FEM model of the RC frame

Fig. 16. Geometry of the investigated structure

Modelling of the concrete frame and the connection nodes was defined as specified in Chapter 4 with the following material data, see in Tab. 1 and 2:

Tab. 1. Classifications of the designed concrete and steel

\begin{tabular}{ccc}
\hline Used materials & \multicolumn{2}{c}{ Classifications } \\
\hline Concrete & C20/25 & $f_{c k}=20 \mathrm{~N} / \mathrm{mm}^{2}$ \\
\hline Steel reinforcement & S500B & $f_{y k}=500 \mathrm{~N} / \mathrm{mm}^{2}$ \\
\hline
\end{tabular}

Tab. 2. Classifications of the designed mortars

\begin{tabular}{cc}
\hline Classification of mortar & Compr. strength $f_{m}\left[\mathrm{~N} / \mathrm{mm}^{2}\right]$ \\
\hline Baumit M30 (M3) & 3 \\
\hline
\end{tabular}

The used masonry unit is the so-called "classic" solid small brick with dimensions $6.5 * 12 * 25 \mathrm{~cm}$, and each of the elements were cutted into three uniform pieces to take into consideration the scale of the RC test frame (Fig. 17p.

The mean compressive strength of the masonry unit (data of the factory) is $f_{k}=10 \mathrm{~N} / \mathrm{mm}^{2}$. The normalized compressive strength of the cutted units $(6.5 * 12 * 8)$ was calculated by EC6, that is $f_{b}=8.57 \mathrm{kN} / \mathrm{mm}^{2}$. The average thickness of both mortar layers is $3.5 \mathrm{~mm}$, and the whole surface is covered with mortar.

The static test loading of the one-bay, two-storey reinforced concrete (RC) frames are consisted lateral uniaxial, monotonic increasing loading $(V)$ at the top beam of the frame besides constant $(100 \mathrm{kN})$ vertical load applied on both columns (Fig. 18).

The suggested sophisticated model was built up by the specifications were introduced in Chapter 5 in accordance with the above mentioned material data. The same parameters were used in every calculation.

The models (see Fig. 19) of the FEM calculations and the results of the nonlinear calculations are presented below, see in Fig. 20, 21, and 22, All of the calculations were made according to the Eurocode 6.
The value of the horizontal displacements at the top of the frame is seen in Tab. 3

Tab. 3. Displacement at the top of the RC frame from the different models

\begin{tabular}{|c|c|c|}
\hline Type of model & Force $[\mathrm{kN}]$ & $\begin{array}{c}\text { Displacements at the top } \\
\text { of the frame [mm] }\end{array}$ \\
\hline Equivalent strut model & & 9,144 \\
\hline Mesh surface model & 100 & 11,052 \\
\hline New suggested model & & 18,703 \\
\hline
\end{tabular}

As it can see in Tab. 3 the calculated top displacements are very far to each other. At top lateral load $\mathrm{V}=100 \mathrm{kN}$, the result of the calculated top displacement using the suggested sophisticated model is twice bigger than in the case of the equivalent strut model.

To determine which model gives the more accurate results an experimental research must be made, which is under preparing at BME Laboratory in Hungary. The next step to verify the suggested sophisticated model and in the same time to develop a usable stress-strain relationship wherewith the non-linear behaviour of the masonry could be taken into consideration.

\section{Conclusions}

Three different finite element models - taking practical aspects into consideration - of the masonry infilled reinforced concrete frames were introduced in this article according to the $\mathrm{Eu}-$ rocode 6 :

- the "classic" equivalent compressed diagonal strut model by the main rules of material characteristics of masonry of Eurocode 6 , which were specified with the nowadays science publications,

- a mesh surface model with membrane or shell finite elements, and with a new method to be able to model the connection 


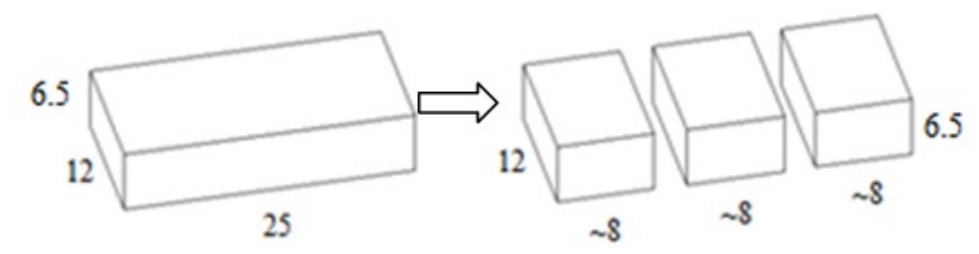

(a) $6.5^{\star} 12^{\star} 25 \mathrm{~cm}$

(b) $6.5^{\star} 12^{\star} 8 \mathrm{~cm}$

Fig. 17. The "classic" solid small brick in Hungary

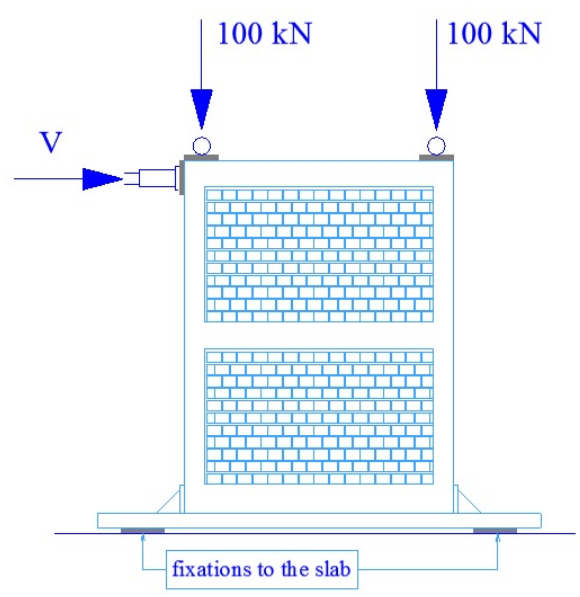

(a) Loading scheme of the test frame
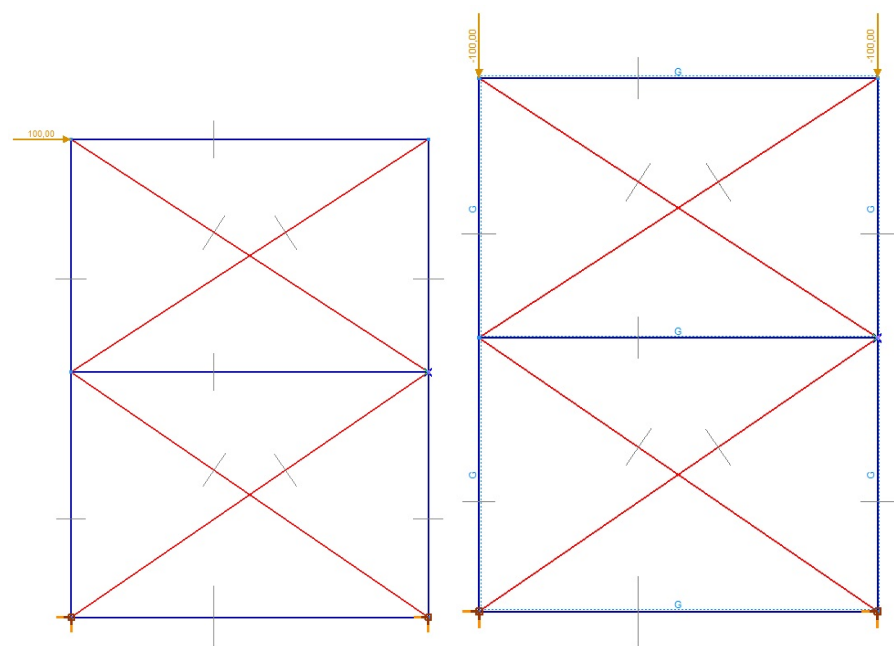

(b) Static loads in the FEM model

Fig. 18. Loading system

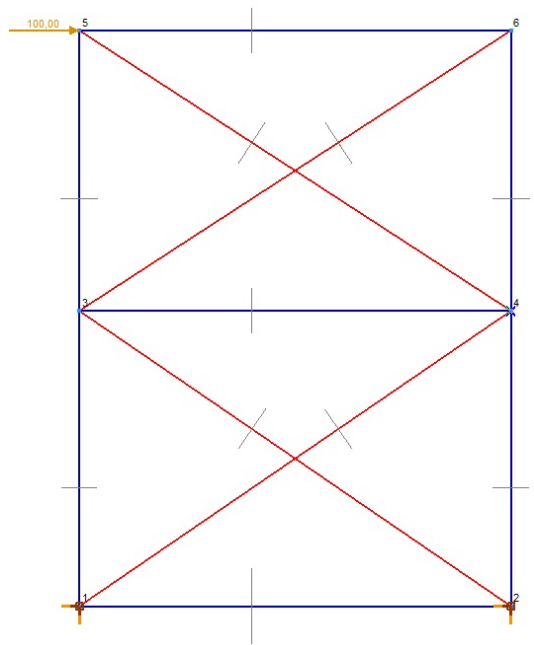

(a) Equivalent strut model

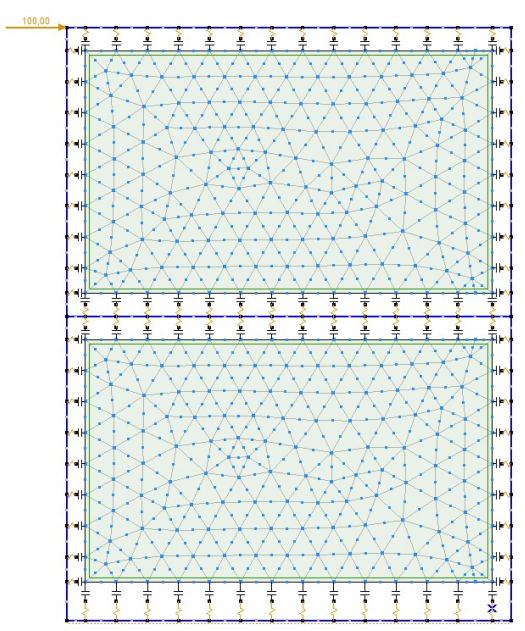

(b) Mesh surface model

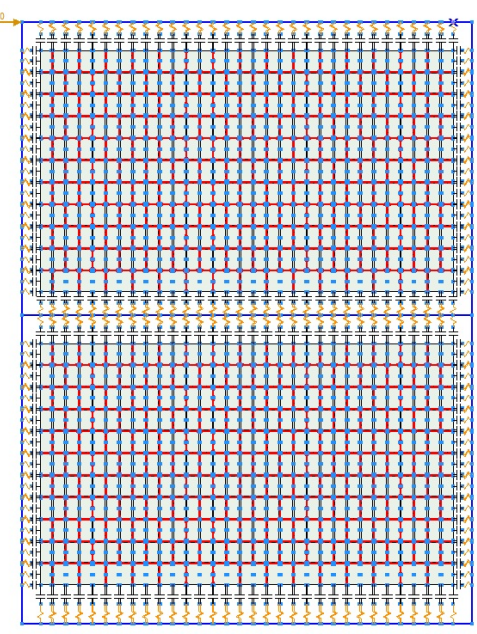

(c) Suggested sophisticated model

Fig. 19. Different models

between the steel reinforced concrete frame and the masonry infill,

- a new suggested sophisticated model, in what the masonry units and the mortar layers were defined with different finite elements. A new method was introduced to replace the mortar layer with two compressed strut. The equivalent normal $(E A)$ stiffnesses of the struts were defined in compact formulas (See Formula (14), (16), (23) and (24)).

With these modelling techniques and methods can be examined:
- the compressive and the tensile stress of the infill masonry wall,

- the length of the compression zone and the gap between the infill masonry and the $\mathrm{RC}$ frame,

- furthermore, more accurate deformations (in the small displacements domain) of the reinforced concrete frame as well.

Otherwise the results which were presented through the numerical example showed quite big difference in the top displacements, but it was expected. Because of the simplicity of the equivalent strut model and also using the mentioned mate- 


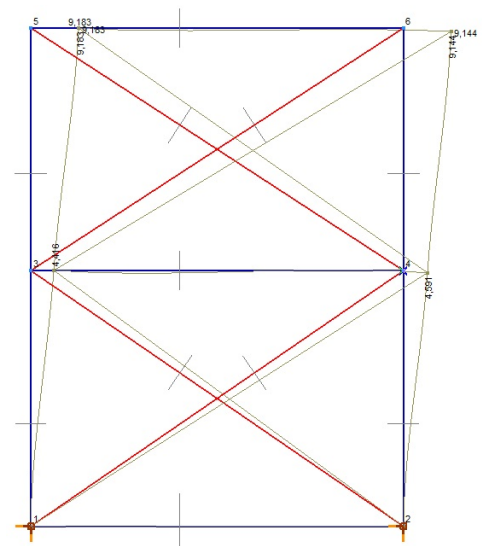

(a) Equivalent strut model

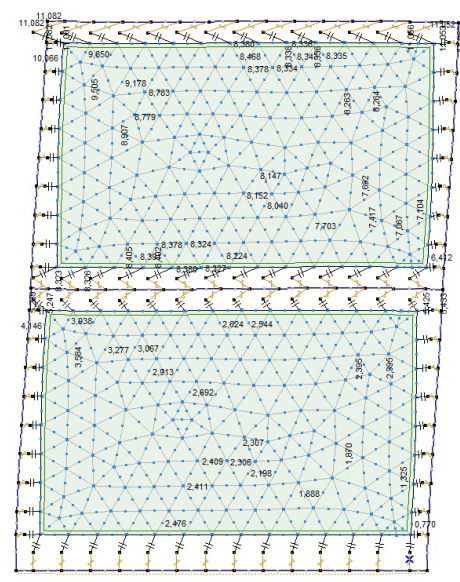

(b) Mesh surface model

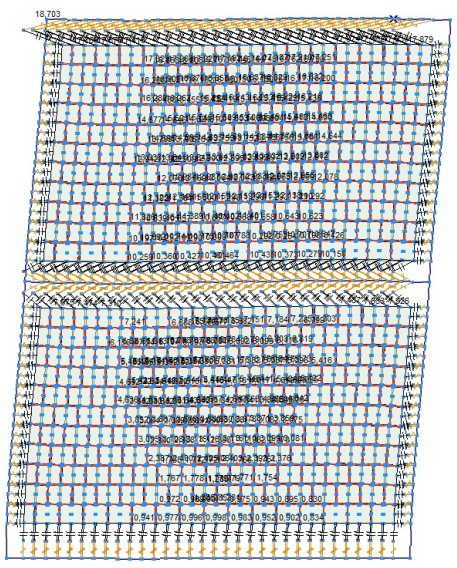

(c) Suggested sophisticated model

Fig. 20. Horizontal displacements [mm]

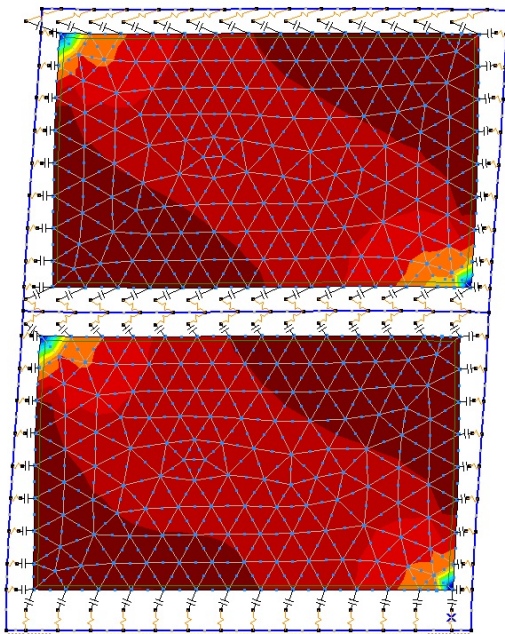

(a) Mesh surface model
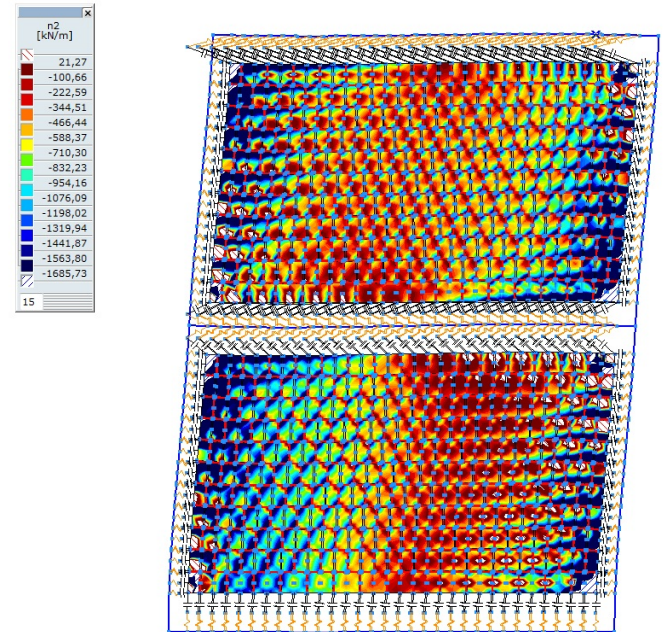

(b) Suggested sophisticated model
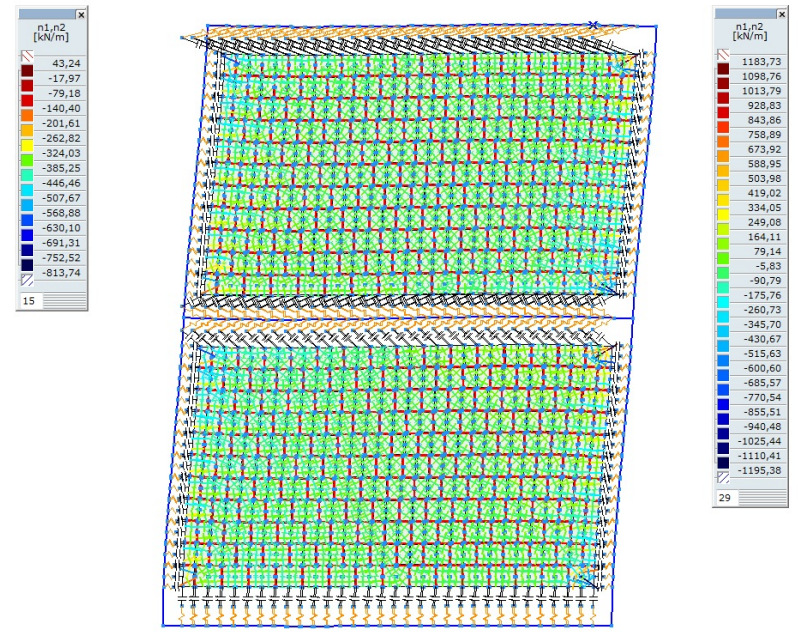

(b) Suggested sophisticated model

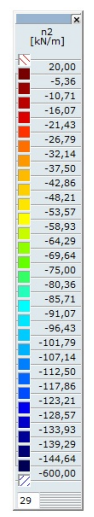

Fig. 21. Principal force $n_{2}$

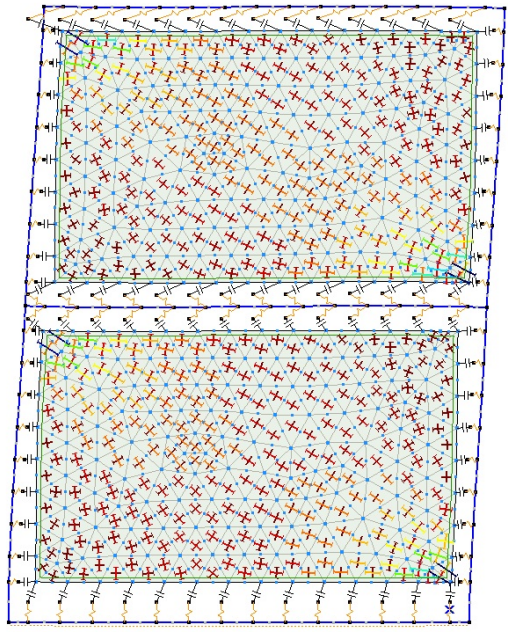

(a) Mesh surface model

Fig. 22. Principal force directions

rial data in accordance with EC are not able to describe the behaviour of a such as considerably complex structure. Neither the non-linearity of the infill masonry, nor the local failure modes are not able to be modelled with equivalent strut model.
The verification of the models is needed, that's why an experimental study is going to be starting soon at the laboratory of BME. 


\section{Objective of further research}

Modelling according to the presented procedures was performed using a FEM software developed for practising structural engineers.

Further research is required; however we must surely be performed by a FEM software developed for scientific use in order to be able to define more detailed and much more accurate models.

Experimental results are needed to verify the presented modelling methods, also specify the useful characteristic values of the material properties of the masonry unit and the mortar.

\section{References}

1 Eurocode 6 EN 1996-1-1:2009, Design of Masonry Structures, 2009. European standard.

2 Baran M, Sevil T, Analytical and Experimental Studies on Infilled RC Frames, Int. Journal of the Physical Sciences 5(13) (2010), 1981-1998.

3 Bell D K, Davidson B J, Evaluation of Earthquake Risk Buildings with Masonry Infill Panels, New Zealand Society for Earthquake Engineering Inc. 2001 Conference, 2001, pp. Paper No. 4.02.01.

4 Braz-Cesar M T, Oliveira D, Barros R C, Comparison of Cyclic Response of Reinforced Concrete Infilled Frames with Experimental Results, 14th World Conference on Earthquake Engineering (Beijing, China, Unknown Month October 12).

5 Dakhakhni W W, Elgaaly M, Hamid A A, Three-Strut Model for Concrete Masonry-Infilled Steel Frames, Journal of Structural Engineering 129 (2003), no. 2, 177-185, DOI 10.1061/(ASCE)0733-9445(2003)129:2(177).

6 Dawe J L, Seah C K, Behaviour of masonry infilled steel frames, Canadian Journal of Civil Engineerings 16 (1989), no. 6, 865-876, DOI 10.1139/189129.

7 Dincel B, The Roles of Masonry Infill Wall sin an Earthquake, 2009, available at http://www.dincelconstructionsystem.com Dincel Contruction System, Paramatta, Australia.

8 Dulácska E, Földrengés elleni védelem, egyszerú tervezés az Eurocode 8 alapján (in Hungarian)(Earthquake protection, simple design based on Eurocode 8$)$, 2009. Practical guide.

9 Fódi A, Effects influencing the compressive strength of a solid, fired clay brick, Periodica Polytechnica - Civil Engineering 55 (2011), no. 2, 117128, DOI 10.3311/pp.ci.2011-2.04, available at http://www.pp.bme.hu/ ci/2011_2/pdf/ci2011_2_04.pdf

10 Hamid A A, Drysdale R G, Concrete Masonry under Combined Shear and Compression Along the Mortar Joints, ACI Journal 77 (1980), no. 5, 314 320.

11 Haris I, Hortobágyi Zs., Modelling cast-in-situ reinforced concrete frame stiffened by masonry wall using FEM software, Central Europen Congress on Concrete Engineering (Visegrád, Hungary, Unknown Month 17), Proceedings of CCC2007 (fib), 2007, pp. 469-474.

12 Holmes M, Steel frames with brickwork and concrete infilling, Institution of Civil Engineers (London, England, 1961), ICE Proceedings, Vol. 19, 1961, pp. 473-478, DOI 10.1680/iicep.1961.11305, (to appear in print). E-ISSN: 1753-7789.

13 Magenes G, Pampanin S, Seismic Response of Gravity-load design frames with masonry infills, 13th World Conference on Earthquake Engineering (Vancouver B.C. Canada, June August 1), proceedings, 2004. Paper No. 4004.

14 Mainstone R J, On the stiffness and strength of infilled frames, Proc. Inst. Civ. Eng., Struct. Build., Instn. of Civil Engrs., London, EnglandR, 1971, pp. 57-90. Paper 7360S.
$15 \ldots$, Supplementary note on the stiffness and strength of infilled frames, Build. Res. Establishment, London, England, 1974. Current Paper CP13/74.

16 May I M, Determination of collapse loads for unreinforced panels with and without openings, Proceedings of Instn. of Civil Engrs., Vol. 71, London, England, 1981, pp. 215-233, DOI 10.1680/iicep.1981.2149, (to appear in print).

17 Murty C V R, Jain S K, Beneficial influence of masonry infill walls on seismic performance of rc frame buildings, 12th World Conference on Earthquake Engineering (Auckland, New Zealand, January 30 ).

18 Lourenço P B, Alvaregna R C, Silva R M, Validation of a Simplified Model for the Design of Masonry Infilled Frames, Masonry International (2006), 15-26. ISSN 0950-2289. 19:1.

19 Polyakov S V, Masonry in Framed Buildings; An Investigations into the Strength and Stiffness of Masonry Infilling (1957). Moscow (In English translation).

20 Puglisi M, Uzcategui M, López J F, Modelling of masonry of infilled frames, Part I: The Plastic Concentrator, Elsevier Engineering Structures 31 (2009), 113-118, DOI 10.1016/j.engstruct.2008.07.012.

21 Puyol S, Benavent-Client A, Rodriguez M E, Smith-Pardo J P, Masonry Infill Walls: An Effective Alternative for Seismic Strengthening of Low-rise Reinforced Concrete Building Structures, 14th World Conference on Earthquake Engineering (Beijing, China, Unknown Month October 12), 2008.

22 Saneinejad A, Hobbs B, Inelastic Design of Infilled Frames, Journal of Structural Engineering 121 (1995), no. 4, DOI 10.1061/(ASCE)07339445(1995)121:4(634). Paper No. 6682.

23 Seah C K, Universal Approach for the Analysis and Design of Masonryinfilled Frame Structures, PhD. Thesis, University of New Brunswick, Canada, 1998.

24 Shing P B, Mehrabi A B, Behaviour and Analysis of Masonry-infilled Frames, Progress in Structural Engineering and Materials 4 (2002), no. 3, 320-331, DOI 10.1002/pse.122.

25 Smith S B, Lateral stiffness of infilled frames, Journal of the Structural Division, ASCE 88 (1962), 183-199.

26 _ Behaviour of square infilled frames, Journal of the Structural Division, ASCE 92 (1966), 381-403.

27 Smith S B, Carter C, A method of analysis for infilled frames, Proc. of Instn. of Civ. Engrs., Vol. 44, 1969, pp. 31-48, DOI 10.1680/iicep.1969.7290, (to appear in print). E-ISSN: 1753-7789.

28 Tasnimi A. A., Mohebkhah A., Investigation on the behaviour of brick infilled steel frames with openings, experimental and analytical approaches, Engineering Structures 33 (2011), no. 3, 968-980, DOI 10.1016/j.engstruct.2010.12.018.

29 Wood R H, Plastic composite action and collapse design of unreinforced shear wall panels in frames, Proceedings of Instn. of Civil Engrs., Vol. 65, London, England, 1978, pp. 381-411, DOI 10.1680/iicep.1978.2952, (to appear in print). 